\title{
EVALUADOR, A NOVELA DE NOÉ JITRIK
}

\author{
Afrânio Mendes Catani \\ Ana Paula Hey
}

* Dr. Professor na Faculdade de Educação da Universidade de São Paulo (USP), São Paulo, Brasil. E no Programa de Pós-Graduação em América Latina (PROLAM - USP). Pesquisador do CNPq. E-mail: amcatani@usp.br

** Dra. Professora no Departamento de Sociologia da Faculdade de Filosofia, Letras e Ciências Humanas da Universidade de São Paulo (FFLCH - USP), São Paulo, Brasil. E-mail: anahey@usp.br

Resumo: O objetivo do presente artigo é apresentar, em linhas gerais, a novela Evaluador (2002), de autoria do professor e crítico argentino Noé Jitrik (1928), docente na Universidade de Buenos Aires. Valendo-se do professor Segismundo Gutiérrez, aposentado e integrante do Conselho responsável pelo conjunto das avaliações acadêmicas em nível universitário de seu país, Nitrik, ao longo de cento e oitenta páginas, costura uma trama a respeito da criação de situações delirantes envolvendo o juízo sobre ações e valores intelectuais acerca daquilo que se impôs à sociedade com o nome de "avaliação". O tom sarcástico adotado pelo autor/narrador, aparentemente desapaixonado, perpassa todo o livro, apresentando uma realidade com dupla face em que quase tudo possui e, ao mesmo tempo, não possui sentido pleno.

Palavras-chave: Avaliação. Juízo. Comissões de avaliação. Novela. Ficção. Noé Jitrik.

\section{THE EVALUATOR, THE NOVEL BY NOÉ JITRIK}

Abstract: The purpose of this text is to present, in general terms, the novel The Evaluator (2002), by the Argentinian professor and critic Noé Jitrik (1928), a professor at the University of Buenos Aires. Making use of Segismundo Gutierrez, a retired professor who is a member of the Council responsible for the nationwide higher education academic evaluations, Nitrik, along the 180 pages of the novel, builds a plot on the hilarious situations involving the judgment of actions and intellectual values about those things which were imposed on society under the name of "evaluation." The sarcastic tone adopted by the author/narrator, apparently passionless, pervades the whole book, presenting a drik.ouble faced reality in which almost everything has and has not, at the same time, a full meaning.

Key words: Evaluation. Judgment. Evaluation Committees. Novel. Fiction. Noé Jitrik.

La investigación es así, la realidad se escapa por todas partes: tres cuartas partes de conjecturas

y una cuarta de desencanto. (Fala do Professor Hermógenes Goldstein)

À memória dos amigos queridos

Pedro Krotsch (1942-2009) e

Alberto Pla (1926-2008),

que nos ajudaram a conhecer melhor a Argentina. 
Universidad del Centro de la Província de Buenos Aires, Tandil, 30 de agosto de 2007, quinta-feira à noite. Conferência de abertura do V Encontro Nacional e II Latinoamericano, "La Universidad como objecto de investigación". Plateia lotada. No palco do auditório o coordenador da mesa, Pedro Krotsch, recepciona e apresenta o conferencista, o professor e crítico literário argentino Noé Jitrik (1928), também autor de contos, novelas, ensaios críticos, literários e históricos. A partir de 1960, Jitrik publicou mais de 50 livros, fundou e dirigiu revistas literárias, além de lecionar em várias universidades em seu país e no exterior e escrever roteiros para filmes. Desde 1997 dirige o Instituto de Literatura Hispanoamericana da Universidade de Buenos Aires. Recebeu, ainda, uma série de doutorados honoris causa e vários prêmios literários. Pedro Krotsch foi hábil em apresentá-lo, mas ainda assim demorou alguns minutinhos nessa tarefa. Noé Jitrik sacou o texto de "una carpeta" e, após agradecer a calorosa recepção, leu com toques de picardia e comentários paralelos o trabalho "Relato especulativo sobre dichas y desdichas de la universidad", que aparece nas páginas desta revista.

A conferência foi breve, menos de 40 minutos, tendo agradado a todos. Terminada a sessão, fomos falar com ele. Solicitamos a autorização para a publicação de sua fala no Brasil, trocamos nossos e-mails e, no dia seguinte, ele nos escrevia dando o seu $\mathrm{OK}$. Quando já nos despedíamos, de forma meio matreira nos perguntou se conhecíamos uma novela que ele havia publicado em 2002, intitulada Evaluador (México: Fondo de Cultura Econômica, 182 p.). Ante nossa negativa, sorriu e acrescentou: "Se vocês a lerem, acho que vão gostar. É divertida!" Voltamos a Buenos Aires e, no mesmo dia, compramos o livro. É de Evaluador que passamos a falar a partir de agora.

Evaluador tem como epígrafe um expressivo trecho extraído de O Castelo, de Franz Kafka, que é o seguinte:

Em suma, como se podia ver de longe, o Castelo respondia às expectativas de K. Não era um velho castelo feudal nem um palácio de construção recente, mas sim uma ampla construção composta de alguns edifícios de dois andares e de um grande número de casas pequenas, construídas uma ao lado das outras.

Noé Jitrik declara na contracapa do livro que a justiça, bem como seu estranho efeito sobre os seres humanos, foi uma grande obsessão de Kafka, levando-o a escrever alguns dos maiores textos da literatura mundial. "Algo menos universal, o 'juízo - não a justiça - sobre ações e valores intelectuais que incidem sobre centenas de milhares de pessoas, pesquisadores, acadêmicos, 
escritores e meros postulantes -, isso que se impôs com o nome de 'avaliação' e que foi crescendo como uma planta parasitária na sociedade contemporânea", é o objeto da novela do escritor argentino. As cento e oitenta páginas, impecavelmente dotadas de um aspecto grotesco e frio, esboçam uma situação delirante em que a inteligência é a grande derrotada e o poder, como metáfora da demência, visto com suas redes obscuras e asfixiantes.

Dividida em nove capítulos com extensões praticamente homogêneas - I. Os anúncios; II. O castelo; III. O Centro Único; IV. Cada vez menos; V. A ciência colocada em xeque; VI. Dois jardins diferentes; VII. O presidente; VIII. O retorno das águas; IX. O tempo gira redondo -, Evaluador possui um narrador desapaixonado que observa um acontecer de dupla face, que não tem sentido e, ao mesmo tempo, possui sentido pleno: um sentido irônico, devastador e, citando uma vez mais a Nitrik, "uma roda da fortuna em que todo valor desaparece no mar de uma exatidão de linguagem e de um extremo controle de sua trama insólita". O juízo narrado constitui-se em um sarcasmo, "o poder em uma ilusão, os personagens em caricaturas grotescas e a realidade em um espelho partido".

No primeiro capítulo, "Los anuncios" (p. 9-26), logo nas linhas iniciais, somos apresentados ao personagem narrador, o professor Segismundo Gutiérrez, antigo docente que se encontra aposentado de seu trabalho na universidade após toda uma vida voltada ao ensino e à pesquisa. No momento em que começamos a leitura, somos informados que o professor Gutiérrez dedica a maior parte de seu tempo a sua atividade no "Consejo" (Conselho). Não se detalha explicitamente o que seja este órgão burocrático, mas logo se fica sabendo que é uma agência de fomento à pesquisa. Suas jornadas de trabalho são consumidas em:

leer papeles sin interés, solicitudes, mamotretos variados y pretenciosos, sino también hacer informes, emitir juicios, dar opiniones, decidir el destino de personas a quienes no conocía y que querían casi siempre por medio de frases hechas o lugares comunes, obtener un cargo, una promoción para quienes ya lo tenían, un subsidio para vagas tareas que nunca llevarían a cabo, cosas que, por otra parte, no estaban en sus manos otogar aunque sí conceder (p. 9-10).

Em suma, o professor Segismundo Gutiérrez “era un evaluador", que exercia a penosa, porém prestigiosa e complicada atividade de emitir juízos (p. 10).

Após aposentar-se, o exercício de realizar avaliações se constituía em uma poderosa dose de trabalho que, a exemplo de uma droga, o mantinha vivo e ativo mas, ao mesmo tempo, "lo vaciaba, lo exterminaba, lo enfrentaba cada 
día con nuevas imposibilidades" (p. 11). Entendia sua tarefa como algo que the parecia inútil, "eso de evaluar a otros, con que detestable derecho, para dar o quitar qué, para reconocer qué. Pero razonable, se decía que a veces aparecia algún valor, alguien a quien de verdad correspondia premiar,

sin contar con el hecho general, equitativamente pensaba, de que algo hay que hacer para encontrar un equilíbrio entre merecimientos $\mathrm{y}$ carencias y entre alguien que tiene y no lo merece y, no hay modo de eludir el problema, un tercero tiene que juzgar, alguien a quien a priori se le crea $y$, vistos los resultados, alguien a quien no se le cree nada pero se finge que se le cree para que se sienta respectado y autorizado y haga lo que ningún otro, más sensato, quiere hacer (p. 12-13).

O professor Gutiérrez, um ano antes de começar a "honorária e honorífica" tarefa de avaliar os textos de outros, bem como as avaliações de outros avaliadores, estava trabalhando com papeis e documentos do legendário Gumersindo Basaldúa, envolvendo todo um conjunto de mitos sobre ele, além das várias lacunas e de tentativas de chantagens. As pesquisas sobre Basaldúa assinalavam caminhos controversos; ora indicavam que ele vivera parte de sua vida entre os índios, ora que havia supostamente escrito um livro a que ninguém tinha (ou tivera) acesso intitulado Breve descripción de paisajes y costumbres de los naturales de la región pampeana, ou ainda que tenha sido um herói das querelas civis na Argentina - estávamos nos esquecendo: toda a ação se passa no país de Borges, de Gardel, de Sarmiento, de Rodolfo Wash, de Pedro Krotsch, de Alberto Pla, de Maradona e de tantos outros -, o que talvez seja a justificativa para a sua longa permanência no deserto (p. 14). ${ }^{1}$

O professor conversava a respeito das incertezas em sua investigação envolvendo seu fugidio personagem com Eugenia Fioravanti de Gutiérrez, sua esposa há trinta anos, quando recebeu duas cartas: a primeira, da Universidade da Califórnia, com informações sobre o desaparecimento, das bibliotecas da instituição (e também da biblioteca do Congresso dos Estados Unidos), do suposto livro de autoria de Basaldúa - é encontrada apenas a ficha da obra, mas como tendo sido escrita por outro desconhecido, Gustavo Bazterrica; a outra carta, da Presidência da República, continha ofício assinado pelo "diretor de despacho de la Secretaría General de la Presidencia” (p. 23), acompanhado de

1 Jitrik prossegue, entre as páginas 14 e 18, levantando uma série de divertidas conjeturas sobre Gumersindo Basaldúa: quem seria, quais suas ações, suas hipotéticas fugas, a eliminação de qualquer informação a seu respeito por parte do exército, sua participação em conspiração antirrosista, sua carreira de latin lover etc. 
um decreto, cujo artigo primeiro era o seguinte: "Créase El Centro Nacional Único de Evaluación (CNUE) que reunirá todas las dependencias y organismos que en la actualidad llevan a cabo tal función" (p. 23) - os demais artigos esclareciam que o Centro era subordinado à Secretaria Geral, bem como sua integração, instalação física, orçamento etc.

A narração irônica do autor vai explorando os considerandos do decreto, que explica a necessidade da concentração do conjunto das atividades de avaliação existentes na Argentina em apenas um organismo centralizado.

Todo apuntaba a concentrar; en primero lugar, concentrar las historias de los solicitantes de modo tal que siempre se supiera lo que intentaban hacer a fin de evitar superposiciones y dirigir sus pasos en una sola, precisa y razonada dirección; luego, concentrar a los evaluadores más capaces en un lugar adecuado para poder cumplir con las finalidades del presente decreto y, por fin, concentrar todas las actividades que de una u otra manera exigían evaluación: investigaciones científicas, concursos literarios, solicitudes de ingreso a puestos, becas, premios, designaciones honoríficas, organización de estructuras de enseñanza y todo aquello que requiera de una opinión autorizada (p. 24).

Segismundo Gutiérrez fica estarrecido com o que lê, considerando o decreto "obra de un fanático o de un delirante o de un adepto al totalismo" (p. 24). Havia outros papeis no envelope, sendo um deles sua designação, após muitos elogios, como "membro activo del Centro Nacional Único de Evaluación", esclarecendo-se ainda que o avaliador, por meio de uma resolução complementar, receberia uma justa gratificação por seus serviços, para que ele pudesse concentrar-se exclusivamente em tais funções.

Em sua perplexidade, Gutiérrez não deu muita atenção a outro papel que também estava no envelope, onde se podia ler "Plan de translado al local del Centro Nacional Único de Evaluación”, em que lhe concediam 24 horas para preparar uma bagagem simples e forneciam outros detalhes para que pudesse chegar ao heliporto da Presidência e, dali, em um helicóptero reservado, viajar à sede do Centro (p. 25-26).

"El castillo" (p. 27-45), o segundo capítulo, inicia-se com o professor se preparando para a viagem. Como todo bom scholar, possui malinha fácil de preparar: algumas peças de roupa, seu diário, "los lexotaniles, las píldoras digestivas, los tés calmantes" (p. 27). Levava consigo, junto ao corpo, uma pasta contendo os documentos que conseguira reunir sobre Basaldúa, com a finalidade de prosseguir trabalhando. Experimentava uma sensação ambígua: ao 
mesmo tempo em que se sentia apreensivo pela viagem, sentia-se pela primeira vez considerado, em sua longa carreira de avaliador, pois viajaria em um helicóptero especial, com tudo muito organizado, lugares marcados, soldados pegando bagagens e as colocando nas naves. Não houve praticamente tempo para as despedidas e não se informou para onde eles seriam levados (p. 27-30). Ao chegar ao destino, após cerca de duas horas de viagem, constatam que o CNUE, que se encontrava situado em uma antiga residência no campo, que pertencera à família Santainés, fora totalmente restaurada e adaptada para ser a sede do órgão governamental dedicado à avaliação. Situava-se em um prado verdíssimo, deslumbrante e bem cuidado que encantara a todos, sendo que tal prado circundava a casa preparada para abrigar 135 avaliadores, mulheres e homens (p. 35-36). O professor Segismundo Gutiérrez e seus colegas - com prenomes como Rudecindo, Etelfredo, Benigno, Hermógenes, Epigmenio, Artemisa, Calixto, Saturnino, Epifanio, Telésforo, Emérito - são recebidos pelo licenciado Antenor Sepúlveda, novo diretor administrativo do CNUE à entrada do edifício-sede, construído originalmente por Hermenegildo Santainés em 1915 e, como destacado, agora pertencente ao Estado. O diretor e seus três adjuntos (Anselmo, Antonio e Anacleto) dão as boas vindas aos avaliadores; os quatro encontram-se bem penteados, bem vestidinhos (e com roupas bastante semelhantes), fazem todos os movimentos de forma sincronizada e provocam uma observação de Gutiérrez: "los cuatro nombres tienen la misma sílaba al comienzo" (p. 38).

Antonio Errázuriz, um dos diretores adjuntos, explica que os avaliadores em breve receberiam os documentos relativos à organização do centro e avança em sua fala:

Ustedes ya lo saben, son 135 , ni uno más. Cinco por cada letra del alfabeto: cinco evaluadores cuyo apellido empieza con A, cinco con B y así siguiendo; incluso hemos podido integrar con cinco evaluadores los grupos de las letras finales, la X, la W, la Y, la Z. No fue fácil pero se logró - acotó con orgullo - . Cada grupo tiene asignada una sala de trabajo que está situada en el sector del último piso, en torno a un pasillo al que dan, por otra parte, las 135 habitaciones que les están destinadas: las salas de trabajo configuran el corazón del piso. Les bastará salir del dormitorio para entrar en la que corresponda sin mayores vacilaciones, directamente. Esto es la disposición física: lo importante es desde luego el concepto. En cada sala se tratarán temas o expedientes cuya letra inicial es la sala del grupo; los evaluadores de la sala A evaluarán solicitudes o temas de personas cuyo apellido empieza con A y así sucesivamente (p. 39-40). 
As reações à fala de Errázuriz foram variadas, com alguns tomando notas (o que é incômodo, quando se faz em pé), outros balançando a cabeça afirmativamente e muitos com expressões de espanto. O professor Gutiérrez berrou: "Esto es una locura!" O professor Epigmenio García, por sua vez, defendeu os procedimentos, destacando que com este sistema

cada grupo evaluador podía ver toda la historia de un solicitante, todos los pedidos que está haciendo a diferentes instituciones, todos los éxitos o fracasos que tuvo en cada subsidio, beca o designación que obtuvo, todas las candidaturas de que es objeto; en fin, cada caso podía ser examinado como una totalidad y, por lo tanto, cada resolución tendrá en cuenta las anteriores y el conjunto de su personalidad (p. 40).

Errázuriz ignora as manifestações e prossegue em seu delírio, acrescentando que em cada sala haverá uma mesa e seis cadeiras, necessárias para acomodar os avaliadores e um assistente, assim como algumas mesinhas contendo os processos a serem examinados e um grande e moderno computador de última geração, no qual aparecerão todos os antecedentes de cada caso (p. 40-41). Para ele, o modus operandi adotado no processo de avaliação realizado pelo Centro é "sencillo y claro" e este "sistema hará todo más fácil, no más superposiciones, no más contradicciones, no más protestos, no más presiones: ustedes tienen en sus manos todo el sistema, ustedes tienen todo el poder" (p. 41).

A um questionamento do professor Benigno Castorena, que diz não poder avaliar temas que não são de sua especialidade, e que isso poderá ocorrer em razão, por exemplo, do sobrenome de um determinado solicitante iniciar-se com C ("puede ser que yo no esté en condiciones epistemológicas de dar una opinión" - p. 42), Antenor Sepúlveda contesta que sempre haverá alguém no grupo que poderá resolver dilemas dessa natureza (p. 42).

Entretanto, o professor Gutiérrez ficou decepcionado com o fato de não haver perguntas acerca do caráter clandestino ou reservado do Centro, pois aparentemente ninguém, além dos avaliadores e dos burocratas, sabiam que existia o CNUE.

O capítulo se conclui com uma confusão desencadeada pelos empregados que haviam retirado as malas e apenas as devolviam se recebesses gorjetas e isso se complica, pois a maioria das valises não possuíam etiquetas que as identificassem (p. 43-45).

"El Centro Único" (p. 46-64), terceiro capítulo, principia com o detalhamento da origem da casa que estava abrigando o CNUE, cujo proprietário, Hermene- 
gildo Santainés, era um riquíssimo "estanciero". Ele construiu o local utilizando materiais provenientes de quase todas as partes do mundo, dotando a residência de inúmeras salas, quartos e ambientes dos mais variados. Inaugurou-a com uma festa nababesca. Entretanto, Hermenegildo tinha uma fraqueza: amava o jogo. Durante a festa de inauguração

lo perdió todo, la casa recién terminada, los campos en los que la propiedad se estiraba, los muebles, enfín, todo. Derrotado, se fue del lugar con lo puesto esa misma noche, sin despedirse, sus invitados ni siquiera se enteraron de que la fiesta había perdido todo sentido... (p. 47).

A partir daí, ninguém habitou o casarão e nem aqueles que o haviam ganho, pois os impostos eram astronômicos. A venda também tornou-se impossível, pois não existiam clientes para semelhante despropósito - a dívida havia crescido de tal maneira que o Estado teve que ficar com a casa, mesmo sem saber o que ia fazer com ela. Ficou fechada durante décadas, até que surgiu a ideia do CNUE, após radical processo de restauração (p. 47).

Os 135 avaliadores que passaram a ocupar os aposentos foram convidados por carta pelo Presidente da República e na porta dos quartos encontravam-se os nomes de cada um deles, em ordem rigorosamente alfabética, que se iniciavam à direita da escada com os da letra $\mathrm{A}$ e terminavam à esquerda com os da letra Z. "El pasillo trazaba un círculo completo en cuyo corazón [...] estaban las salas de trabajo, veintisiete en total" (p. 50). O local era deslumbrante, com bosques maravilhosos, sendo os quartos bem ajeitados e equipados com tudo que era necessário, inclusive um computador (p. 52). O restaurante, por sua vez, possuía 20 mesas com 7 cadeiras cada, sendo tais mesas redondas, "con manteles prestos y cubiertos" (p. 54). Os garçons, que eram os mesmos que haviam recolhido as malas e que possuíam um aspecto meio brutalizado, passavam repetindo a mesma cantilena: "tenemos empanadas de jamon y queso, pizza rellena, sandwich de milanesa y pay de manzana. Cada unidad cuesta un peso" (p. 56). O ambiente torna-se pesado e meio deprimente, uma vez que além de não poderem escolher os companheiros de mesa, ainda eram obrigados a pagar para comer (p. 56).

As indagações e discussões surgiam a todo momento: Segismundo Gutiérrez desejava saber onde se encontravam, qual era a localização exata do castelo; a professora Carmela Gandía, colega de sala, observava com ênfase que o sistema ao qual se encontravam submetidos 
permite que estemos a cubierto de cualquier tipo de presión; ningún solicitante sabrá quién lo evaluó y si protesta debe hacerlo ante personas que no necesiten esforzarse por guardar el anonimato. Yo creo que por eso ni siquiera nosotros debemos saber donde estamos, con menos razón los solicitantes (p. 58).

A comunicação dos avaliadores com seus familiares ou com seus escritórios era, na prática, quase impossível, em razão de haver apenas um aparelho na sala do administrador, mas um defeito na linha, alegava-se, impedia sua utilização. Aparentemente, outra forma seria através da internet, mas também não se podia contar com ela (ao longo dos capítulos verifica-se que as mensagens chegam ao destino ou são respondidas quando interessam à administração). Assim, a única maneira de se enviar mensagens para o "exterior", sugere um dos auxiliares do diretor do CNUE, é a de escrever bilhetes ou cartas e a administração se encarrega de remetê-las (p. 59-60). Os professores Gutiérrez e Goldstein e a professora Arminda Guerra concluem que se encontram presos em local ignorado (p. 63-64).

Gutiérrez escreve ao Presidente da República através do computador de seu quarto, sem esperança de que a mensagem chegue ao seu destino. Necessitava dos esclarecimentos básicos para entender o que estava ocorrendo, o que era tudo isso, "El Centro por empezar, esa casa, ese sistema, ese lugar, ese espacio, esas nubes, inclusive, que convertían la ya plena noche en una caverna sombría, indescifrable" (p. 64).

"Cada vez menos" (p. 65-82) é o quarto capítulo do livro de Nitrik. Segismundo Gutiérrez, Hermógenes Goldstein e Arminda Guerra integravam a mesma comissão avaliadora, em que pese as distintas disciplinas a que se dedicavam: Gutiérrez era um literato voltado à história, o professor Goldstein era biólogo marinho, enquanto a professora Guerra atuava na área de antropologia social (p. 67).

Chegam ao castelo outras 100 pessoas para trabalhar com os avaliadores, exercendo a função de supervisores e auxiliares junto a cada uma das 27 comissões - recordando: uma comissão para cada letra do alfabeto (p. 68). Esses novos são designados ironicamente por Gutiérrez como "la tropa de auxiliares de evaluación" (p. 72).

Enquanto tentavam caminhar um pouco pelo jardim, os dois professores e a professora que tinham seus sobrenomes iniciados pela letra $G$ são interrompidos em suas reflexões por gritos e correrias: dois homens e uma mulher bastante magros, vestidos com farrapos, com olhos enormes e fixos, arcados e descalços, são perseguidos e insultados, aos gritos, por dois outros homens 
robustos: "te voy a dar", "locos de mierda" e outras falas menos edificantes são ouvidas pelos avaliadores, que ficam atônitos (p. 72). Perguntado o que era aquilo, um dos auxiliares de Sepúlveda nada responde e pede que voltem ao edifício para continuar o trabalho.

Em seu retorno ao quarto, o professor Gutiérrez, ao abrir seu computador, depara-se com uma mensagem do Presidente da República, respondendo ao que ele havia escrito anteriormente. A maior autoridade do país esclarece que Gutiérrez não deveria se preocupar com o estado de saúde de Dona Eugenia Fioravante de Gutiérrez e, também, no que dizia respeito a seus bens e contas bancárias. Comenta que sua esposa encontrava-se em "recuperação". O velho professor quase fica em estado de choque e tenta usar o telefone, na sala do administrador. Inútil, pois o aparelho continuava com defeito. Ao retornar, encontra a porta de seu quarto escancarada, bem como a de seus amigos (p. 76-77 e 79).

Em seguida recebe carta, em papel timbrado, da University of Califórnia, Irvine, dizendo que a instituição possui o livro Breve descripción de paisajes y costumbres de los naturales de la región pampeana, de Gumersindo Basaldúa, mas que o mesmo havia desaparecido. Na carta ainda pode-se ler que as correspondentes do Professor Gutiérrez foram punidas disciplinarmente por haverem retido em seu poder a obra - em seguida o livro reapareceu. Tentam cobrar uma fortuna para providenciar uma fotocópia do volume, enviando trechos do mesmo. Gutiérrez logo percebe tratar-se de uma falsificação grosseira (p. 80-81).

O capítulo V, "La ciencia puesta a prueba" (p. 83-100), inicia-se pela descrição mais detalhada dos 5 componentes da comissão G, posteriormente expandida para 7, a exemplo de todas as outras. A professora Carmela Gandía era "especialista em física no relativista y en ecologia"; o professor Epigmenio García era "fisiólogo y químico"; a professora Artemisa Galán "inginiera de materiales"; o professor Benito Galeana especialista em "cuerpos celestes" (p. 83) - a eles agregavam-se os professores Gutiérrez, Goldstein e a professora Guerra.

Gutiérrez pergunta-se: "Como entenderse entre ellos, provenientes de disciplinas tan diversas, algunas epistemológicamente tan raras, y con ellos desde una perspectiva personal o humana?" (p. 83). Com os docentes Goldstein e Guerra havia se dado bem, em termos pessoais, mas não ia muito além disso. Acrescente-se o fato de que os funcionários mais se assemelhavam a seguranças, o que contribuía para uma grande sensação de angústia (p. 84).

O Dr. Calixto Zamudio, encarregado das comissões F, G, H, I e J esclarece que dois outros auxiliares chegaram para ajudar no trabalho, acrescidos a outros 54 avaliadores - que se incorporaram aos 135 originais (p. 85). 
Mas o que mais chocou a maioria dos avaliadores foi a explicação que o Dr. Calixto forneceu sobre os procedimentos avaliativos: existiam processos assinalados na capa com um pequeno círculo azul, que indicava que em avaliações prévias, realizadas por experts, já haviam sido consideradas de bom nível, encontravam-se plenamente justificadas. Assim,

ustedes deberán, simplemente, por respeto al trabajo preliminar, aprobar las respectivas decisiones mediante dictámenes razonados. En cuanto a los expedientes que no tienen ninguna marca no hay mayor decisión que tomar, han sido vistos escrupulosamente y se ha determinado que no pueden di ninguna manera ser beneficiados con un subsidio o premio o designación o promoción; a ustedes les cabe la importante responsabilidad de explicar por qué se los deniega, puesto que la filosofía del Centro es explicar siempre, enfrentar la frustración de unos pocos antes que negarla y soportar después los nocivos efectos de la actitud. Este centro no admitiría un trato semejante, puesto que somos todos científicos, nos debemos respeto, los que empiezan hoy sus carreras en algún momento, estarán en lugar que ocupan ustedes ahora; es el sistema lo que hay que preservar (p. 85-86).

Os auxiliares começam a distribuir os processos aos avaliadores e Noé Jitrik, através do professor Gutiérrez, faz descrições cruéis do Dr. Saturnino Fleischman e da Dra. Aurelia Vélez, auxiliares, no que se refere aos trajes, aos penteados, aos odores (p. 86-87).

Alguns avaliadores concordam plenamente com o regulamento e iniciam de imediato o trabalho, enquanto outros são contra e acabam não executando suas tarefas. As contradições se tornam notórias: há projetos interessantes, que demandam pequenas somas financeiras, mas que devem ser rechaçados. Por outro lado, há outros completamente absurdos, que solicitam muito dinheiro e já se encontravam previamente aprovados. Os avaliadores consultam a Dra Aurelia, que explica detalhadamente que os mesmos não podem ser aprovados em hipótese alguma (p. 88). O clima vai se tornando cada vez mais tenso, o professor García acha os critérios justos e o professor Gutiérrez se pergunta: "Si las decisiones ya están tomadas, para qué nos necesitan a nosotros?" (p.89). Ao que o professor Goldstein responde: "talvez no nos necesitan" (p. 89). "Lo que se quiere es terminar con la ciencia y entregar los pocos fondos que existen a los charlatanes que están cerca del poder" (p. 90).

Em quase todas as salas das comissões, e não apenas daquela marcada com a letra $\mathrm{G}$, se ouvia uma gritaria confusa, devendo estar ocorrendo o mesmo movimento de revolta e de perplexidade (p. 91). 
O professor Castorena, amigo de Gutiérrez, passa mal e é socorrido por pretensos enfermeiros (p. 91-94). Goldstein e Gutiérrez o procuram por todo o castelo e não o encontram. Acabam por enveredar-se pelos arquivos e saem novamente nos jardins, perto das grades que isolam o edifício do espaço exterior. Ao chegar lá, Gutiérrez identificou, do lado de fora, sua esposa, Eugenia Fioravante e, de imediato, como se algum projétil o houvesse atingido na cabeça, e "antes aun de comprobar si era en efecto ella y de preguntarse qué hacia en ese lugar, cayó redondo al suelo, no escuchó ni vio nada más” (p. 100).

$\mathrm{O}$ atendimento do professor Gutiérrez por colegas médicos e seu transporte até seus aposentos, onde lhe ministram soro e lhe prescrevem uma alimentação mais leve (p. 101-104), marca o início do capítulo VI, "Dos jardines diferentes" (p. 101-119). Ao lado de sua cabeceira se estabelece um breve diálogo entre os colegas mais próximos. A professora Guerra comenta que durante anos lutou-se pela melhoria do sistema de avaliação e, diante da situação em que se encontram desabafa: "me siento muy inutil, todo parece resuelto en outra parte, todo es tan grotesco" (p. 104). O professor Goldstein concordou:

No creo que haya mucho que esperar de este tremendo engaño; esta casa que más parece un cárcel, unos archivos que no sierven para nada, unos funcionarios cuyo aspecto patibulario no condice con la dignidad de la ciencia; en verdad estoy muy desconcertado. Ha visto los proyectos que nos han mostrado? Es ridículo. Una maestría en lancería de lujo! Por quien nos toman ? [...] Lo que yo creo es que estamos asistiendo a un cambio radical de civilización [...] Viejas formas son atacadas y lo que las remplaza es demencial, como si las formas y las relaciones giran en redondo, todas locas, y no hallaran el ponto del reposo (p. 104-105).

O professor Goldstein acrescenta, ainda, que a criação do CNUE era uma utopia, "tal vez ésta sea uma utopía fallada" (p. 107). O professor Gutiérrez pensou: "esa idea es de Echeverría y de la primera parte de Martín Fierro, pero no lo dijo (p. 108).

A doutora Vélez também vai ao quarto do professor Gutiérrez e lhe pede que assine algumas resoluções, ao que ele contesta; "Pero si no se resolvió nada!". Sim, concorda ela, "no es que se resolviera [...] ya estaba resuelto cuando llegó y lo que hay que hacer ahora es avalarlo". "Qué? - dijo el profesor Goldstein - , la maestría en lancería de lujo, la beca de Armo Gómez para su tesis sobre los sueños intermitentes del secretario privado del presidente, la mecánica de los tragamonedas a instalar en las escuelas primarias, el doctorado en la lírica de los bolsistas?" "Si”, dijo la doctora Vélez bajando los ojos. "Yo 
no firmo esa basura", dijo El profesor Goldstein" (p. 109). A Dra. Vélez, após um desabafo, deixa os aposentos de Gutiérrez sem haver obtido as assinaturas.

Gutiérrez recebe outra mensagem do Presidente da República, que lhe deseja melhorias, informa que a Sra. Eugenia Fioravanti de Gutiérrez desapareceu e que o professor Benigno Castorena, que fora hospitalizado, "no pudo superar físicamente la descompensación que sufrió. Como un homenaje de respecto a su memoria será enterrado en el jardín de la casa...” (p. 112). Todos estranham como o Presidente sabia de tudo e fazem menção ao romance 1984, de George Orwell (p. 113).

Vão ao suposto enterro do professor Castorena. Nada há no jardim onde ele seria enterrado, além de um buraco com a terra ao lado. As pessoas que preparavam a tumba desapareceram. De repente, ouvem-se vozes e gritos desagradáveis e eles chegam a ver novamente pessoas vestidas com farrapos, magras, quase cadavéricas, desdentadas, todas gritando em uníssono e agarradas ao alambrado, "tejidos en una composición concentracionaria o propia de los pintores flamencos que trataban de mostrar y explicar al mismo tiempo las demasías de la locura" (p. 115-116). Tais pessoas, acrescenta o narrador, "recordaba los sobrevivientes de los campos de concentración" (p. 116).

Há uma correria generalizada quando surge um grupo de homens vigorosos e vestidos com guardanapos, correndo desde a casa e gritando. "En sus manos tenían látigos cortos algunos y bastones otros y se veía que su objeto eran los seres agrupados junto a la barda" (p. 116-117). Alguns homens eram os mesmos que haviam recolhido as malas na chegada dos avaliadores a casa (como foi dito em linhas anteriores, eles também atuavam como garçons, eram truculentos e agora tudo se revelava: "personas dudosas y patibularias que ponían en duda la jerarquía científica del lugar y que, ahora aparecía con claridad, también revistaban en esa estructura que era, ya no se podía dudar más, un loquero, un manicomio, un asilo de monstruos" (p. 117).

Um dos empregados entregara ao professor Gutiérrez, dias antes, um pequeno bilhete em que dizia que o professor Castorena estava no portão quando Gutiérrez desfaleceu, bem como a sua esposa. Isso o deixa desconcertado e mais inseguro ainda. Seus pensamentos, entretanto, são interrompidos por uma forte chuva, que dispersa o grupo e o obriga a retornar às pressas ao Centro, para se refugiar da tempestade (p. 119).

"El presidente" (p. 120-138), o sétimo capítulo de Evaluador, é praticamente uma crônica da chuva e da tempestade incessante; "el jardín ya está intransitable" (p. 125). Todos ficam olhando o cair das águas pelas janelas dos quartos. 
Os trabalhos de avaliação prosseguem, com a necessidade da apreciação de vários outros projetos que possuíam o círculo azul na capa e que eram totalmente absurdos em suas temáticas e em seus conteúdos. Os processos recebiam o apoio dos professores Galeana, Gandía e García, mas eram rechassados pelos demais. Os relatos seguintes narram os acalorados embates entre as duas facções existentes na comissão G. Quando o professor Gutiérrez está para abandonar a sala, em razão do absurdo das discussões, ingressa o licenciado Antenor Sepúlveda que, todo bem composto e vestido à maneira típica dos burocratas de órgãos públicos da área da educação ou dos domínios científicos afirmou: "Señores evaluadores: la inundación sigue progresando y ya ha cubierto el jardín; hay riesgo de que el agua entre a los archivos que están en los sótanos. Le he dado instrucciones al máster Venancio Aguirre para ir sacando los expedientes y llevarlos a lugar seguro; en este momento todo el personal del archivo está trabajando en eso" (p. 130-131).

Era domingo, o professor Gutiérrez estava em seu quarto, tentando trabalhar no computador e se encontrava completamente entediado e reflexiona: "Si algo hay opuesto a la esperanza ese es una tarde de domingo"(p. 133). À frente do computador, depara-se com mensagem de Alexander Moore, identificando-se como sendo da Universidade da Califórnia, que tenta aplicar-lhe um golpe, pedindo U\$S 3.000 para que possa lhe remeter o livro de Gumersindo Basaldúa (p. 134-135).

Nesse domingo tedioso começa a pensar sobre o Presidente. Como se chama? Seu primeiro nome é Apolodoro, o que não dizia muita coisa. Era um militar, um general, embora tenha sido um coronel até antes de assumir o poder (ou, talvez, fosse tenente coronel ou tenente general). Se o prenome pouco dizia, o sobrenome também não acrescentava muito: Ibarlucía,

de indubitables reminiscencias vascas. Vasco como Basaldúa? Parientes, quizás? Tal vez algún remoto parentesco, después de todo el presidente debía tener, como todo el mundo, otros apellidos que confluyen en el principal y lo nutren, a veces los que están en segundo término, porque suelen corresponder al universo materno, gravitan más que el que está en primero, gravitan en la memoria, en la línea de sangre, es sabido que en el imaginario militar la imagen materna es más decisiva, aunque imponderable, que la paterna, por lo general tan débil que el hijo decide entrar a la carrera de las armas no para superar al padre sino para presentarle a la madre una imagen de fuerza" (p. 137-138). Indaga-se Gutiérrez se o sobrenome do Presidente não seria Ibarlúcia Basaldúa (p. 138). 
Através do computador o Presidente anuncia a evacuação do Centro, informando que todos deveriam se dirigir a um "lugar seguro". Golpes na porta do quarto do professor Gutiérrez, acompanhados de gritos e de falas de ordem de comando indicam que era o momento de sair do prédio - não se sabia para onde e nem como iriam sair. De qualquer maneira, agarrou seus poucos pertences e a pasta contendo os documentos sobre a quase inexistente vida de Gumersindo Basaldúa (p. 138).

"El regreso de las aguas" (p. 139-160) principia com a constatação de que já não chovia mais e nas ruas e estradas que circundavam o CNUE tudo estava seco (p. 139). Gutiérrez caminhava com os demais avaliadores, por uma rota de terra que se desenvolvia entre alambrados que cercavam vastas extensões de terra (p. 140). O professor Benito Galeana comenta que a estrada estava seca e os campos inundados e explica a razão disso: os responsáveis são os ingleses que, quando construíram

los ferrocarriles y los primeros caminos los hicieran a más de un metro sobre el nível del campo [...] Ahora las lagunas están volviendo; mire las garzas y los flamencos ahí nomás: recuerdos ancestrales de esas águas que usted ve, vingativas y triunfantes (p. 141).

O professor Gutiérrez realiza mais uma série de considerações sobre Gumersindo Basaldúa, talvez parente distante do Presidente. Há, inclusive, interpretações que atribuem a Basaldúa o papel de traidor. Será que era isso que o Presidente queria ocultar? Mas talvez Basaldúa não havia traído a ninguém (p.144-145).

A caminhada continua e alguns avaliadores vão conversando e se discute acerca da continuidade do trabalho. O professor Galeana parecia desconsolado e o professor Gutiérrez procura acalmá-lo, dizendo que o mais provável é que vão prosseguir suas tarefas em algum outro lugar. O professor García, veemente defensor dos pontos de vista do sistema vigente perde o controle e estrila com Gutiérrez: "Usted no entiende! Usted no entiende que el sostén del edificio científico reside en la eliminación de la inteligencia!” (p. 148). A discussão acaba sendo interrompida, pois os caminhantes chegam a uma quase encruzilhada e tentam decifrar a placa que estava com algumas letras faltando. Após muito parlamentar, descobrem que estavam a cinco quilômetros de Puelche (p. 149).

Puelche é a maior reserva de água que possui o país. Estavam parados sobre milhões de metros cúbicos de água. O professor Rudecindo Funes, geólogo e vulcanólogo, esclarece que a grande quantidade de água "en las profundidades 
de la tierra la fertilizam e impiden que esto se convierta en un desierto. Lo que se llama 'pampa húmeda' es simplemente Puelche, pero pocos lo saben. Esta inundación es Puelche que sale de su caverna y ocupa lo que era suyo" (p. 150).

Chegam a um novo edifício e o licenciado Antenor Sepúlveda é quem os recebe mas, estranhamente, afirma: "Soy el doctor Telésforo Zapata, director de este estabelecimiento" (p. 152). Os professores Gutiérrez e Galeana se olham assustados, pois viam os mesmos bigodes negros, o mesmo penteado para trás, "los ojos refulgentes pero sombríos y el traje oscuro y un modo de hablar que traía, a Gutiérrez, ecos de voces o de situaciones conocidas" (p. 152). O doutor Zapata vai dando as instruções preliminares, explica que cada um receberá um número, haverá uma cama a ser ocupada num estabelecimento coletivo ( $\mathrm{p}$. 153). Cada avaliador recebe uma ficha com um número - Gutiérrez recebeu o número 425; a partir de agora, entendeu que deveria ser tratado como um número, exatamente o 425 (p. 154). Um funcionário lhe diz o seguinte: "Póngase la ficha en la camisa, en el lado izquierdo, para que se vea bien". O 425 obedeceu, "le ajustó el alfiles que estaba en el reverso, como es de uso en los congresos científicos, y se puso detrás del 715...” (p. 154).

São obrigados a se deslocar na chuva e no terreno encharcado para irem a outro edifício, acabando por sujar-se (p. 156-158). Chegando ao novo estabelecimento, um funcionário disse em voz bem alta, que eles deveriam comer algo, sendo necessário, entretanto, banhar-se entes de ocupar os lugares que lhe haviam sido designados. Quando os atendentes chegaram com as bandejas, "solo traían mate cocido y galletas de esas que porque resisten a la humedad y el desgaste son llamadas marineras" (p. 158). Tomam banho em banheiro coletivo, homens de um lado, mulheres do outro, sendo todos obrigados a desnudar-se, desvencilhar-se das respectivas roupas - que seriam limpas e secadas pela administração, a tempo de poderem ir ocupar os lugares que lhes haviam sido designados quando chegaram, "este sítio que debía ser un refugio en cual podrían reponerse del desastre del que habían sido víctimas" (p. 159).

O último capítulo, de número IX, "El tiempo gira en redondo" (p. 161179), demonstra que as coisas não se apresentavam bem para o avaliador 425 - e, também, para os demais, que compartilhavam as mesmas e penosas circunstâncias. São alojados em "colchones sin sábanas, destripados, apenas cubrían elásticos de alambre, muy diferentes, por cierto, esas camas no solo a las de sus ya remotas casas sino incluso a las del Centro Nacional Único de Evaluación" p. 161-162).

Nas novas e precárias instalações o trabalho dos avaliadores se reinicia, e uma pequena mesa de rodinhas e "llena de carpetas" (p. 164) é colocada à frente de 
todos os integrantes do grupo G, com a ordem para que tudo fosse analisado. 425 reclama, alegando a impossibilidade de se trabalhar em tais condições; outros concordam com ele, mas o 413 aceita prosseguir e as atividades recomeçam, com os processos sendo examinados pelos avaliadores "sobre las rodillas, sentados en las camas, haciendo equilíbrio pero con el mismo celo y rigor con el que otrora habían hecho evaluaciones en escenarios muy diferentes" (p. 166). 425 se revolta contra os projetos que lhe dão para avaliar e que deve referendar, uma vez que estavam marcados com o selo azul. Outros avaliadores também se revoltam e dizem que estão fazendo papel de tontos (p. 167). A confusão se generaliza, Gutiérrez joga no chão todos os processos que pode e os pisoteia. O trabalho se interrompe (p. 168).

O Dr. Fleischmann entra na sala, censura a rebeldia dos avaliadores e anuncia que o "señor presidente", Apolônio Ibarlucía Basaldúa, os visitará em breve (p. 169). Gutiérrez descreve, em breves palavras, a chegada do presidente:

...sintió que el tiempo giraba en redondo, la escena se parecía extraordinariamente a la de la llegada al Centro Nacional Único de Evaluación, solo que ahora no bajaban de un helicóptero que el presidente había puesto a disposición de los evaluadores para conducirlos a ese lugar en que se terminarían todos los problemas de la evaluación, sino que el presidente habría bajado de su proprio helicóptero, así como tampoco estaban iniciando una tarea tendiente a consolidar el desarrollo científico del país sino que arrastraban su cuerpo como si hubieran salido, apenas vivos, de una catástrofe (p. 171-172).

Os avaliadores assistiram a tudo meio desorientados, sem estarem banhados e sem concluir o trabalho para o qual foram convocados (p. 173).

Eles se encontram com o Sr. Presidente e com os internos do manicômio num mesmo espaço físico, num ambiente deteriorado e com os avaliadores com baixíssima autoestima. Os internos tinham, em geral,

cuerpos deformes y semidesnudos, cráneos puntiagudos de mujeres desdentadas, descalzos casi todos y emitiendo gruñidos que indicaban que los integrantes de esa concentración o, lo que es lo mismo, los habitantes permanentes de esse sitio, eran locos, disminuidos, cretinos, desechos de la razón y de la genética, olvidados de la sociedad y de la vida (p. 173-174).

Entretanto, o professor Gutiérrez se pergunta: “Que podría decirlos el señor presidente?" (p. 174). Obtém a informação de que o filho do presidente integrava essa massa de desvalidos, estava recluso nesse inferno, 
desechado, impresentable pero no olvidado, tan poco olvidado que acaso la creación del Centro Nacional Único de Evaluación podría haber sido una gigantesca maniobra para ese drama del que la doctora Vélez parecía estar en conocimiento, puesto que sin duda a eso había aludido cuando reprochó a los evaluadores que no tenían corazón (p. 174).

Comenta que quase todos sabem acerca da síndrome do filho do presidente, o Estado Maior do exército e, sobretudo, o Episcopado, "porque tanto el presidente como su esposa hacen dar misas por la salud de su hijo con mucha frecuencia" (p. 174).

O presidente, quando se expressa, dirige-se aos "conciudadanos", "señores evaluadores", "queridos enfermitos". O General Ibarlucía Basaldúa fala acerca dos enfermos, que a ele lhe importam muito, porque

entre ustedes está un ser que me es muy querido, un retoño de mi linaje cuyo sufrimiento me afecta profundamente. Lo he visto hace un momento y está feliz en este lugar donde se lo trata como a todos ustedes, sin privilegios, con amor y preocupación, sin retacear en lo más mínimo los recursos para una recuperación que le permita comunicarse otra vez con su pobre madre (p. 176).

O presidente prossegue, rebatendo comentários que ele considera como absoluta irresponsabilidade, qual seja, que no lugar em que se encontravam existe tráfico de órgãos. Ele nega com veemência, dizendo que apenas gente sem sentimento e sem coração "puede afirmar que las muertes naturales de algunos queridos enfermitos no lo han sido y que aquí se mata gente para vender sus hígados o riñones sanos que, porque no afectan los males que padecen, pueden servir para salvar otras vidas y, además, cuestan mucho dinero" (p. 176).

"Un estremecimiento recorrió las filas de los evaluadores [...] Salgamos de aquí, dijo el profesor Gutiérrez" (p. 176). Todos conversavam e Gutiérrez vai saindo de fininho, sem que nenhum obstáculo tenha se interposto: se podia sair por uma porta do Salão de Atos, por onde havia entrado - ele saiu acompanhado pelos professores Goldstein e Guerra (p. 176-177), e começaram a correr para o lado oposto ao da casa que agora poderiam definir como "asilo o loquero y que para ellos, ni asilados ni locos, podía convertirse en cárcel” (p. 177).

Eles pensavam que ninguém os observava, mas estavam equivocados, pois alguém os via "aunque no desde la casa de la que habían salido sino desde el otro lado del cerco que estaba en el límite del terreno por el qué corrían" (p.178). Chegam a uma construção que tinha o aspecto de um castelo, com quatro an- 
dares. Encontram, em seguida, dois homens e uma mulher, bem vestidos e bem penteados, que os olhavam e que, ao mesmo tempo, estavam

pulcros y tensos, como si quisieran entender quienes eran o qué decían eses seres anómalos que les gritaban pidiendo auxilio al mismo tiempo que miraban hacia atrás, desde donde venían, corriendo también, como lo habían hecho elles, otras personas que, en peores condiciones todavía, aullaban o gemían, no se podía saber a esa distancia, arrastrándose alguno, en especial un ser puro tronco, sin piernas, montado en un carrito que impulsaba con uno solo brazo enfundado en una especie de cuero negro, seguidos a corta distancia por uno grupo de sujetos munidos de látigos, que gritaban: 'Vuelvan acá, locos de mierda`y hacían restallar los látigos como queriendo indicar que los aplicarían sobre sus espaldas (p. 178-179).

$\mathrm{O}$ relato termina de forma melancólica e não menos apavorante:

Los locos de mierda desviaron su camino y huyeron hacia el lado contrario, un monte que se adivinaba de plantas espinosas, hirsuto y rebelde a cualquier criterio de agrado o de utilidad, perseguidos por esos guardianes o tal vez fueran enfermos o doctores, si esos locos eran en realidad locos, o sea enfermos, o lo que sea que, descubriendo a los tres que estaban junto al cerco, se les aproximaron con la misma actitud amenazante $\mathrm{y}$, sin decir palabra, tal vez porque se trataba de otra categoría de personas, los empezaron a empujar, no sin antes arrancar de las manos de un de ellos un portafolios al que se ásia y aventarlo de tal suerte que los papeles que contenía se desparramaron y empezaron a volar por todas partes, ante la irada perpleja y aun aterrada de los que estaban del lado del parque que brillaba a la luz del sol, como para hacerlos volver al lugar del que nunca debían haber salido ( $\mathrm{p}, 179)$.

Ao longo do presente texto deixamos a novela de Noé Jitrk praticamente falar por si. A condensação do livro que realizamos ganha em muito, reiteramos, se lida em conjunto com o artigo "Relato especulativo sobre dichas y desdichas de la universidad", do próprio Nitrik. Boa leitura, é o que desejamos!

\section{REFERÊNCIAS}

JITRIK, Noé. Evaluador. México: Fondo de Cultura Econômica, 2002. 